\title{
Analysis Of Factors That Effect Lecturer Productivity Producing International Scientific Article In Private University: Motivation As A Moderating Variable
}

\author{
Dewi Andriani \\ Universitas Negeri Jakarta \\ Email: dewiandriani_im11s3@mahasiswa.unj.ac.id \\ Dedi Purwana \\ Universitas Negeri Jakarta \\ Email: dpurwana@unj.ac.id \\ Dewi Susita \\ Universitas Negeri Jakarta \\ Email: dewisusita_man@unj.ac.id
}

\begin{abstract}
In accordance with the demands facing global challenges, lecturers are one of the important factors for creating competent university graduates, and the main role of colleges/universities is teaching, research and community service and directed to expand knowledge and open new avenues of science and technology. The purpose of this study is to analyze the factors that affect the productivity of lecturers producing international scientific article in Private Universities by using the Structural Equation Modeling. The data used are primary data by conducting surveys with a total of 310 respondents, and the analysis used includes validity, reliability, multiple linear regression, sobel tests, and hypothesis testing. The results showed that the positive direct effect of Reward System, Transformational Leadership Style, Communication and Motivation on Lecturer Productivity. Furthermore. From the four exogenous variables, Communication proved to be the most dominant influence on Productivity, amounting to 5,132, and also the results of the study showed that the positive indirect effect through Motivation was a moderating variable.
\end{abstract}

Keywords: Reward System, Transformational Leadership Style, Communication, Motivation, Lecturer and Structural Equation Modeling

Received: 31 January 2020 ;

Accepted: 16 March 2020 ;

Publish; June 2020.

\section{How to Cite:}

Andriani, D., Purwana, D., \& Susita, D. (2020). Analysis Of Factors That Effect Lecturer Productivity Producing International Scientific Article In Private University: Motivation As A Moderating Variable. International Journal of Human Capital Management, 4 (1), 87-107. https://doi.org/10.21009/IJHCM.04.01.08 


\section{INTRODUCTION}

Human Resource Management (HRM) designs management systems to ensure that human talent is used effectively and efficiently to achieve organizational goals (Mathis \& Jackson, 2008: 4) through developing human resources to develop organizational infrastructure, improve business processes, or increase knowledge, innovation, or other organizational parameters (Rasool, Samma, Wang, Yan, \& Zhang, 2019). Then, HRM focuses on how to manage employees as human resources (human assets) which are the most strategic elements (Natural, 2015), and are considered as the most important assets in the organization (Safiullah, 2014: 22). While employees as human capital can be interpreted as individuals with talents, abilities, experience, professional expertise, relationships, and others (Mathis \& Jackson, 2008: 4) based on knowledge, education, work competence, and psychometric evaluation ( Parvin \& Kabir, 2011; Pasban \& Nojedeh, 2016). In this case, lecturers can be interpreted as human assets and human capital who are professional educators in higher education institutions and are employed by universities or higher education institutions to carry out teaching, research and administrative tasks in accordance with the subject specialists they have ("Law No. 14 of 2005 concerning Teachers and Lecturers"). Lecturers as employees of an organization, college/university are contributing greatly in the form of skills, knowledge or values (Pelinescu, 2015; Zameer, Ali, \& Amir, 2014) so that lecturers play a very strategic role to achieve the goals of higher education (Nazari, Basri, \& Idris, 2012) in order to create competent university graduates (Agustini, Amanah, \& Harmen, 2014).

According to Nyaribo (2014: 135), the university's main role is teaching, research and community service is a harmonious and mutually beneficial activity (Galbraith and Merrill 2012; Ramsden and Moses 1992; Taylor 2007 in Cadez, Dimovski, \& Groff, 2016). In this context, the role of lecturers in addition to teaching and community service, the role of lecturers is to conduct research, write and publish (RWP) the results of research in international journals which are important activities in universities or higher education institutions as an effort directed to expand knowledge and open new avenues of science and technology. Therefore, through research, universities or higher education institutions make important contributions to the growth and development of a country's vital sectors to encourage national and global development (Ifijeh, Ogbomo, \& Ifijeh, 2018). According to Aithal (2016), higher education institutions must have a goal not only to provide quality education centered on students but also to be involved in creating new knowledge, namely developing good infrastructure for teaching and learning by designing curricula that focus on industry-oriented skills, apply innovative and effective pedagogy (Ahmadein in Implementing the 2030 Agenda at Higher Education Institutions: Challenges and Responses, 2019: 18).

Research and publication are complementary because research efforts and findings can be communicated (Okonedo, 2015). As academics in higher education, lecturers have the responsibility to conduct research, teaching, and development of science (Khazragui \& Hudson, 2014; Su \& Wood, 2012) and lecturers as scientists are to conduct scientific reasoning and research and disseminate them, scientific publications ( Law (UU) No 12 of 2012 concerning Higher Education This is an inseparable obligation for every lecturer in the framework of the Tri Dharma of Higher Education (Ministerial Regulation of the Empowerment of State Apparatus and Bureaucratic Reforms (Permen PAN-RB) Number 17 Year) 2013 on Lecturer Functional Position and Credit Score) Then, each lecturer is required to make scientific journals and be published in Scopus at least once a year, while professors are biennial (Minister of Research, Technology, and Higher Education Regulation of the Republic of Indonesia Number 20 of 2017 Regarding Giving Lecturer Professional Allowance and Honorary Allowance Professor), Sedan Even professors are required to have scientific works or other monumental works that are very special in their fields and receive international recognition (Law No. 14 of 2005 article 49 paragraph 3), and if they are unable to fulfill the mandate, the lecturer allowance and professor allowance is terminated (Nasir, 2017). 
Lecturer productivity as a measure of productivity or performance / work of lecturers (Kim \& Ployhart, 2014; Upev, Chorun, \& Idachaba, 2015) in Indonesia as a researcher, conducts reasoning activities, scientific research and disseminates them or publishes them in the form of scientific papers of national standard and international tend not to be optimal. The productivity of lecturers in Indonesia as indicated researchers tends to be less productive when compared to researchers from Malaysia and Thailand, and this condition is a general reality that occurs in various universities both state universities (Perguruan Tinggi Negeri -PTN) and private universities (Perguruan Tinggi Swasta - PTS) in Indonesia. According to Nasir (2019), currently there are 5,500 people, while there are only 2,250 people doing research and publication of their work, there are still many professors in a number of universities in Indonesia not doing research and publications. "Professors certainly have to do research and publications, not just just enjoy the honor allowance "said Nasir in Padang, Wednesday (3/13/2019) as quoted Antaranews.com. (Higher Education: 2,250 professors do not do research and publications, https://beritagar.id/artikel/berita/2250-profesor-takakukan-riset-dan-publikasi . Accessed March 15, 2019). Based on Kemristekdikti data, in 2016, of 5,216 professors in Indonesia, as many as 1,132 people have already published scopus indexes - a library database containing abstracts and citations of academic journal articles (Higher Education: 2,250 Professors not doing research and publication, https://beritagar.id/artikel/berita/2250-profesor-takAKAN-riset-dan-publikasi . Accessed March 15, 2019).

Table 1 .: Comparison of Indonesian International Publications in the Scopus Period 2010 - April $2016^{1)}$

\begin{tabular}{ccccc}
\hline Year & Malaysia & Thailand & Indonesia & Philippines \\
\hline $2016($ April) & $\mathbf{6 . 6 3 0}$ & $\mathbf{3 . 8 6 4}$ & $\mathbf{2 . 0 6 2}$ & $\mathbf{6 6 4}$ \\
\hline 2015 & $\mathbf{2 4 . 4 6 0}$ & $\mathbf{1 1 . 8 8 6}$ & $\mathbf{6 . 7 0 6}$ & $\mathbf{2 . 2 8 6}$ \\
\hline 2014 & $\mathbf{2 7 . 9 1 1}$ & $\mathbf{1 3 . 2 4 4}$ & $\mathbf{6 . 0 2 0}$ & $\mathbf{1 . 8 8 1}$ \\
\hline 2013 & $\mathbf{2 5 . 0 0 4}$ & $\mathbf{1 2 . 1 7 1}$ & $\mathbf{1 . 7 3 4}$ \\
\hline 2012 & $\mathbf{2 2 . 5 6 4}$ & $\mathbf{1 1 . 8 9 8}$ & $\mathbf{3 . 8 1 1}$ & $\mathbf{1 . 5 8 0}$ \\
\hline 2011 & $\mathbf{2 0 . 6 6 3}$ & $\mathbf{1 0 . 6 9 5}$ & $\mathbf{3 . 2 2 7}$ & $\mathbf{1 . 3 2 9}$ \\
\hline 2010 & $\mathbf{1 5 . 6 6 2}$ & $\mathbf{9 . 9 9 3}$ & $\mathbf{2 . 6 0 2}$ & $\mathbf{1 1 . 4 9 4}$ \\
\hline Total & $\mathbf{1 4 2 . 8 9 4}$ & $\mathbf{7 3 . 7 5 1}$ & & \\
\hline
\end{tabular}

Based on table 1, the number of Indonesian scientific publications indexed by Scopus as of April 2016 ranks Indonesia below Malaysia and Thailand. However, as of April 6, 2018 Mohamad Nasir, Minister of Research, Technology and Higher Education stated that Indonesia succeeded in surpassing Singapore and Thailand, the number of Indonesian international scientific publications was 5,125, while Singapore was 4,948 and Thailand were 3,741, and Malaysia remained superior with 5,999 (Salip Singapore, Indonesia Scientific Publication Ranked 2nd in ASEAN, https://risbang.ristekdikti.go.id/publikasi/berita-media/salip-singapurapublikasi-ilmiah-indonesia-peringkat-2-asean/. Accessed April 12, 2018) . Furthermore, the data obtained that the ratio of productivity of lecturers as writers of international scientific publications in Scopus (International Journal Scopus Indexed) in 3 (three) private tertiary institutions, namely Trisakti University, Bina Nusantara University and Tarumanagara University that the number of publication authors compared to the total number of lecturers owned by each private university are as table 2 as follows: 
Table 2.: Data on International Scientific Articles Publication in 3 (Three) Private Universities in Scopus (International Journal Scopus Indexed) ${ }^{2)}$

\begin{tabular}{|c|c|c|c|c|c|}
\hline \multirow[t]{2}{*}{ NO } & \multirow{2}{*}{$\begin{array}{c}\text { PRIVATE } \\
\text { UNIVERSITY }\end{array}$} & \multirow{2}{*}{$\begin{array}{l}\text { TOTAL } \\
\text { LECTURER }\end{array}$} & TOTAL & PUBLICATION & \multirow{2}{*}{$\begin{array}{c}\text { LECTURER } \\
\text { PRODUCTIVITY RATIO } \\
(\%)\end{array}$} \\
\hline & & & $\begin{array}{c}\text { Publication } \\
\text { writer } \\
\text { (People) }\end{array}$ & $\begin{array}{c}\text { International Scientific } \\
\text { Articles (Documents) }\end{array}$ & \\
\hline 1 & Universitas Trisakti & 895 & 109 & 165 & $12,17 \%$ \\
\hline 2 & $\begin{array}{l}\text { Universitas Bina } \\
\text { Nusantara }\end{array}$ & 1.289 & 731 & 705 & $56,71 \%$ \\
\hline 3 & $\begin{array}{l}\text { Universitas } \\
\text { Tarumanagara }\end{array}$ & 862 & 86 & 114 & $\mathbf{9 , 9 8 \%}$ \\
\hline
\end{tabular}

From table 2. it can be analyzed that the ratio of lecturer productivity which is the result of work or lecturer performance as a researcher in the publication of international scientific works in the 3 (three) private universities tends to be still low, namely $30.40 \%$. That is, it is still far from the provisions regulated as mandated by various regulations and legislation in force as in Permenristekdikti Number 20 Year 2017 Law No 14 of 2005 article 1 paragraph 2 About Teachers and Lecturers, Law No 12 of 2012 article 12 paragraph 2 Regarding Higher Education, PAN-RB Permen Number 17 of 2013, and Regulation of the Minister of Education and Culture of the Republic of Indonesia Number 78 of 2013. Thus, strategic and focused and ongoing efforts are needed to address these problems through strategic policies in the form of stimulus programs through reward systems, transformational leadership styles, communication and motivation in order to increase the productivity of lecturers producing international scientific work. This has become a critical issue and research gap as well as researchers' interest to examine it as the subject matter (Statement of Problem) in this study about "The Effect of the Reward System, Transformational Leadership Style, Communication and Motivation on the Productivity of Lecturers in Private Colleges" as a scientific study.

Based on the problems that have been described, then several problems that need to be investigated. The variables to be investigated are the rewards system (), transformational leadership style $\left(\mathrm{X}_{2}\right)$, communication $\left(\mathrm{X}_{3}\right)$, and motivation $\left(\mathrm{X}_{4}\right)$ as exogenous or independent variables, productivity $(\mathrm{Y})$ as endogenous or dependent variables, and motivation $\left(\mathrm{X}_{4}\right)$ as a Moderating variable. The research constellation model is in Figure 1, and each variable has indicators that will be measured from respondents through a questionnaire and the research constellation model as shown in Figure 1. Thus, it can be formulated that there are 12 (twelve) hypotheses in this study as follows: :

1. Reward System has a direct positive effect on Productivity.

2. Transformational Leadership Style has a direct positive effect on Productivity.

3. Communication has a direct positive effect on Productivity.

4. Motivation has a direct positive effect on Productivity.

5. Transformational Leadership Style has a direct positive effect on Reward System.

6. Transformational Leadership Style has a direct positive effect on Communication.

7. Transformational Leadership Style has a direct positive effect on Motivation.

8. Rewards System has a direct positive effect on Motivation.

9. Communication has a direct positive effect on Motivation.

10. Reward System indirectly has a positive effect on Productivity through Motivation.

11. Transformational Leadership Style indirectly has a positive effect on Productivity through Motivation.

12. Communication has an indirect positive effect on Productivity through Motivation. 


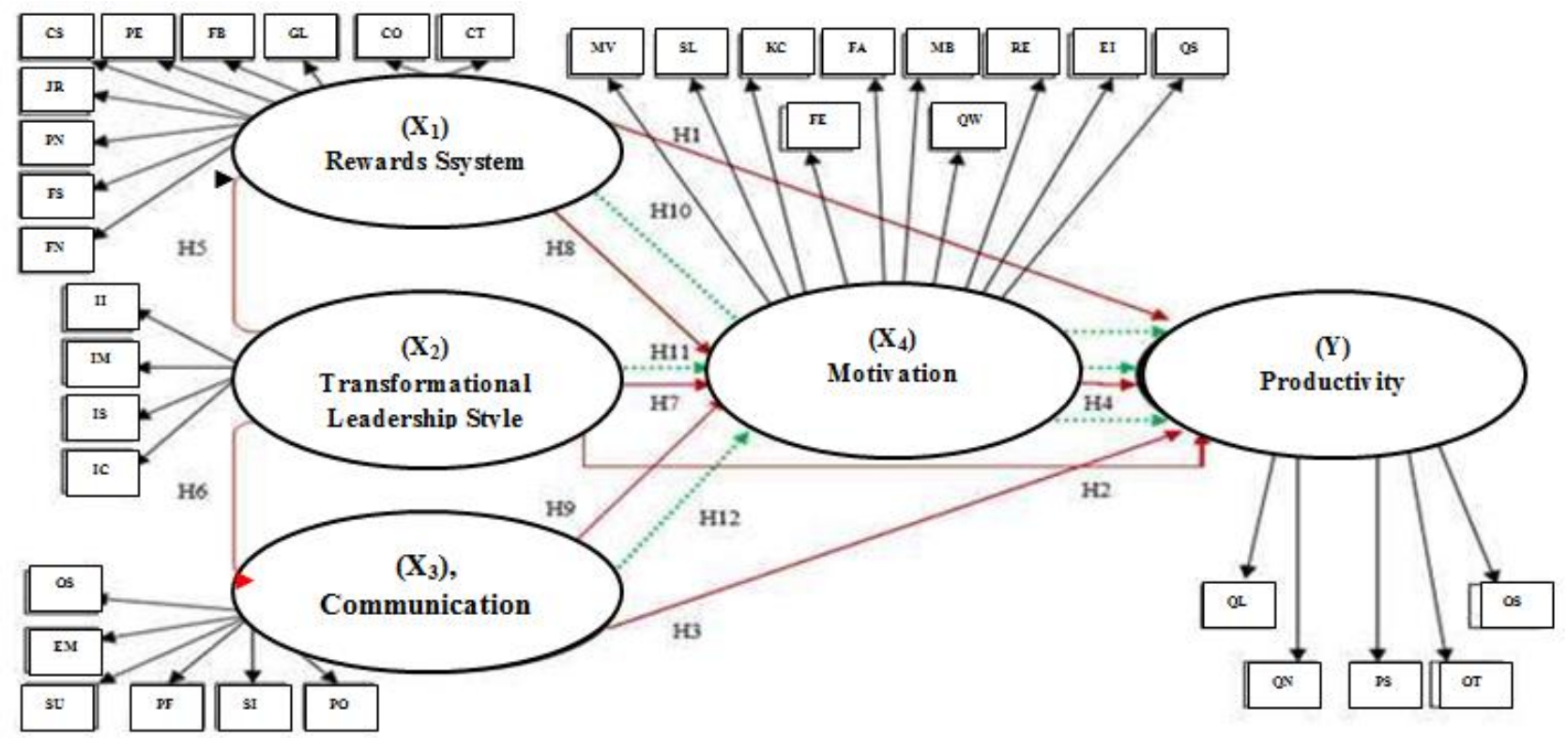

Figure 1: Constellation Model

Source: Various opinions \& publications, developed for research Note:

1. The Indicator of Rewards System $\left(\mathrm{X}_{1}\right)$ as independent variable consists of (1) Financial and Non-Financial Incentives (FN) ; (2) Flexible Schedule (FS) ; (3) Promotion (PN) ; (4) Job Responsibilities (JR); (5) Change in Status (CS); (6) Praise (PE); Feedback (FB) ; (8) Good Leader (GL); (9) Cultivating Organizational Culture (CO); (10) Challenging Task (CT).

2. The Indicators of Transformational Leadership Style $\left(\mathrm{X}_{2}\right)$ as independent variable consist of (1) Ideal Influence (II), (2) Inspiration Motivational or Charismatic (IM); (3) Intellectual Simulation (IS), dan (4) Individual Consideration (IC);

3. The Indicator of Communication $\left(\mathrm{X}_{3}\right)$ as independent variable consists of (1) Openness (OS) ; (2) Empathy (EM) ; (3) Support (SU) ; (4) Positive Feelings (PF) ; (5) Similarity (SI) ; (6) Performance Oriented (PO);

4. The Indicators of Motivation $\left(\mathrm{X}_{4}\right)$ as independent variable consists of (1) Mission, Vision, and Goals of the organization (MV); (2) Skill Level (SL); (3) Knowledge of Completing Tasks (KC); (4) Feelings and Emotions (FE); (5) Facilitating (FA); (6) Management Behavior (MB); (7) Quality of Work Life (QW); (8) Recognition (RE); (9) Employee Involvement (EI) ; (10) Conditions of Service (QS);

5. The Indicators of Productivity (Y) as dependent variable consists of (1) Quality (QL); (2) Quantity (QN); (3) The specified Process (PS) (4) Output (OT) ; (5) Outcomes (OS).

\section{LITERATURE REVIEW}

According to (Leblebici, 2012), an increase in performance can be interpreted as functional and organizational productivity including: quality, namely the ratio to measure how well an organization (or individual, industry, country) to change the input resources in the form of labor, materials, machinery, and others become goods and services. Research performance in the academic world usually refers to scientific progress, mostly published in academic journals (Cadez et al., 2016). According to (Mustapa \& Mahmood, 2016), job performance is a key term that is applied to describe how well an employee's performance is related to his duties, and must be seen as behavior rather than results. According to experts in Okonedo (2015) that the productivity of publications is expressed by the number or quantity of papers published by the 
units selected in a certain time, and the quantity indicators for research for example: the number of publications, citations, and grants (Cadez et al., 2016).

According to Iqbal and Mahmood (2011: 189), productivity of publications are papers published and produced by selected units in a certain time in the form of real results from research and published in professional journals, conference processes, writing books or chapters in books, working with post-graduate students scholars in dissertations, and class projects, carrying out editorial assignments, obtaining patents and licenses, writing monographs, developing experimental designs, producing works of an artistic or creative nature and engaging in public debates and comments. While the understanding of research can be interpreted as a rigorous, systematic, validating, verified, empirical, critical, analyzing and interpreting process of information to answer questions by collecting, verifying, and analyzing information (Ifijeh et al., 2018) and research is an ongoing process, namely seeking the truth or trying to approach reality (Iqbal \& Mahmood, 2011: 189).

According to experts as quoted by Agustini et al., (2014), the notion of productivity is not only "doing something right" to achieve maximum performance, but "the right thing" to achieve maximum effectiveness, namely as what people can produce with less effort and as employee hourly outputs by considering quality as well as improving functional and organizational performance, including quality. According to Kim \& Ployhart (2014), performance is operationalized in terms of employee productivity in the form of an organization / company workforce efficiency to produce outputs. Higher education outputs are in the form of journal articles, books published, chapters in books, technical reports, conference papers, seminar papers, edited works, workshop papers, theses and other types of publications (Ifijeh et al., 2018). Outputs are closely related to human resource activities and performance measures that include efficiency and effectiveness (Upev et al., 2015). Then, Aderibigbe (2017: 76-77) describes that employee productivity is related to the extent to which members of the organization contribute to achieving organizational goals. While organizational success is dependent on employee performance, such as: employees who are creative, innovative, and committed (Al Doghan \& Albar, 2015).

Productivity in the education sector can be taken as a measure of the success of operations of activities that will lead to the realization of the goals and objectives of the sector in the economy as it applies to other forms of business or corporate organization (Adu, 2015), and the effectiveness of higher education institutions must be measured based on research productivity these institutions, the ability to generate new knowledge in the form of publications using their active resources as a result of the institution (Aithal, 2016). From the various descriptions above, the notion of productivity as the dependent variable in this study can be interpreted as an aggregate of lecturers' performance in producing international scientific work in private universities that is influenced by the reward system, leadership style, communication and motivation. With several indicators adopted from (Saeed et al., 2013); (Veliu et al., 2017); (Wamala \& Ssembatya, 2013); (Cadez et al., 2016); Sudhier and Abhila (2011) in (Okonedo, 2015); (Aithal, 2016) as follows: (1) Quality; (2) Quantity; (3) Process specified; (4) Output; (5) Outcomes.

Understanding the reward system as an independent variable in this study can be interpreted as rewards given in accordance with contributions, skills and competencies as an encouragement to have a positive attitude at work in order to increase the motivation and productivity of lecturers in private universities to produce and increase the productivity of international scientific work. With several indicators adopted from (Ibrar \& Khan, 2015); (Upev et al., 2015); (Akafo \& Boateng, 2015); and (Eshak et al., 2016) as follows: (1) Financial and non-financial incentives; (2) Flexible schedule; (3) Promotion; (4) Job responsibilities; (5) Change in status; (6) Praise; (7) Feedback; (8) Good leaders; (9) Fostering organizational culture; (10) Challenging tasks. Effect of a direct reward system on productivity - Human resource management (HRM) focuses on how to manage employees as human resources which is the most strategic element (Natural, 2015) in an organization / company. According to (Ibrar \& Khan, 2015); (Upev et al., 2015); (Akafo \& Boateng, 2015); (Eshak et al., 2016); (Yamoah, 2013); and (Aithal, 2016) which states that a reward or reward system (Wasiu \& Adebajo, 2014) 
is a reward given objectively through fair treatment (Fernandez \& Pitts, 2011) by management (Ndungu, 2017) in accordance with contributions, skills and competencies as an encouragement to have a positive attitude at work in order to increase motivation and productivity. The effect of the reward system directly on motivation.

According to (Natural, 2015), employee motivation as a human resource (HR) is the most strategic element to achieve the organization's mission, vision, and goals (Olusadum \& Anulika, 2018) because there is a positive relationship (Weldeyohannes, 2015) between motivation and productivity / performance (Robescu \& Iancu, 2016; Shahzadi et al., 2014; Zameer et al., 2014); (Mohamud et al., 2017).), That is every organization focuses on what must be done to achieve high levels of productivity or performance (Mohamud et al., 2017; Al Doghan \& Albar, 2015) and sustainable by paying special attention on how individuals can be well motivated through means such as incentives, rewards (Mansor et al., 2014), leadership, etc. (Said, Zaidee, Zahari, Ali; \& Salleh, 2017: 632; Wasiu \& Adebajo, 2014; Muda et al., 2014) and communication patterns (Onanda, 2015). According to Došenović (2016: 107), rewards to employees are one of the activities of human resource management, ie rewards given by companies / organizations to employees for the achievement of performance and a well-designed reward system in the form of salaries, incentives, bonuses, promotions, job security , and others as well as intrinsic / internal rewards, intangible rewards, namely psychological rewards are in the form of rewards for facing new challenges, positive and caring attitudes from employers, and job rotation (Safiullah, 2014: 22).

The effect of the reward system indirectly on productivity through motivation. Employees must be motivated by providing adequate resources including job security, challenging job assignments, participation in decision making, incentives and monetary rewards are the main factors and are priority in motivating people to work (Robescu \& Iancu, 2016; Chandrasekar, 2011). In line with this opinion, (Ibrar \& Khan, 2015) states that the main purpose of financial rewards and non-financial rewards are to attract and retain employees, motivate to achieve high levels of performance, and to obtain and strengthen the behavior desired by employees because of the level of employee productivity. Higher education provides organizations and employees with various benefits (Hanaysha, 2016). In this context, the notion of an award system is the rewards given to employees in accordance with their contributions, skills and competencies as an encouragement that employees have a positive attitude at work to increase motivation and productivity and there is an indirect influence of the reward system on the productivity of lecturers to produce scientific work internationally in private universities through motivation.

Understanding transformational leadership style as an independent variable in this study can be interpreted as the behavior of leaders as agents of change, inspiring increased motivation and productivity of lecturers in private universities to produce international scientific work. With several indicators adopted from (Voon et al., 2011); (Veliu et al., 2017); (Ahmad et al., 2014); and (Aydin et al., 2013) as follows: (1) The ideal influence; (2) Inspirational motivation; (3) Intellectual simulations; (4) Individual consideration. Productivity in organizations basically rests on the human resources owned by the organization as human capital. In this case, private universities (PTS) need leaders who can direct and develop lecturers in accordance with their authority towards the achievement of organizational goals set by communicating effectively (Luthra \& Dahiya, 2015) which have four dimensions consisting of ( 1) ideal influence, (2) charismatic; (3) intellectual simulations, and (4) individual considerations (Voon et al., 2011); (Veliu et al., 2017); (Ahmad et al., 2014); and (Aydin et al., 2013). The influence of transformational leadership style directly on the reward system. Leadership style can be interpreted as a behavior and strategy that can maximize productivity by leaders when trying to influence the performance of their subordinates by implementing a system of rewarding employees..

Employee motivation as a human resource (HR) is the most strategic element to achieve the organization's mission, vision and goals (Olusadum \& Anulika, 2018) because there is a positive relationship (Weldeyohannes, 2015) between motivation and productivity/performance (Robescu \& Iancu, 2016; Shahzadi et al., 2014; Zameer et al., 2014); (Mohamud et al., 2017).), That is every organization focuses on what must be done to achieve high levels of productivity or 
performance (Mohamud et al., 2017; Al Doghan \& Albar, 2015) and sustainable by paying special attention on how individuals can be well motivated through means such as incentives, rewards, leadership, etc. (Said, Zaidee, Zahari, Ali; \& Salleh, 2017: 632; Onanda, 2015; Wasiu \& Adebajo, 2014; Muda et al., 2014) as well as communication patterns (Onanda, 2015). in terms of completing employee work well, on time, and dare to take risks. According to (Bao \& Nizam, 2015), reward systems in organizations must be designed and implemented correctly to reinforce positive behavior that will directly instill positivity to employee performance because the rewards system and organizational procedures help motivate employees to achieve the organization's vision and goals (Gathii \& K'Obonyo, 2017) to improve productivity / performance (Iqbal et al., 2015).

The effect of transformational leadership style directly on communication. According to (Ajala, 2012), the role of effective communication in an organization's work environment is to avoid and resolve various problems that might occur so as to produce stronger morals and more positive attitudes towards work. In this context, leaders who have a transformational leadership style are interpreted to be able to communicate and articulate and define the vision, mission, goals and objectives of the organization / company, and subordinates must accept and acknowledge the credibility of their leaders (Boateng, 2014, 36-37). According to Brandt \& Kakkuri (2016: 120), the findings show that leaders who have transformational leadership styles more often show intelligent, controlled, and transparent communication styles. The effect of transformational leadership style directly on motivation. Transformational leadership style is essentially emphasizing a leader needs to motivate his subordinates to carry out their responsibilities more than they expect (Money, 2017; Iqbal et al., 2015), In the opinion of experts quoted (Ahmad et al., 2014); and (Aydin et al., 2013) that transformational leadership style has four dimensions as follows: first, idealist influence, individual consideration, intellectual stimulation, inspirational motivation, has a strong correlation between transformative leadership behavior and high productivity among employees (Olusadum \& Anulika, 2018). In this context, there is a leader's influence on motivation towards extra effort driven by extrinsic factors on the part of subordinates; namely usyang inspired by the leader himself.

The influence of transformational leadership style indirectly on productivity through motivation. According to (Natural, 2015) which states employee motivation as human resources (HR) is the most strategic element to achieve the organization's mission, vision, and goals (Olusadum \& Anulika, 2018) because there is a positive relationship (Weldeyohannes, 2015) between motivation and productivity / performance (Robescu \& Iancu, 2016; Shahzadi et al., 2014; Zameer et al., 2014; Mohamud et al., 2017) according to (Iqbal et al., 2015), organizational success depends on the leader and his leadership style. Transformational leadership style correlates with employee performance due to the innovative, productive and supportive nature of transformational leaders (Veliu et al., 2017); (Bushra et al., 2011), and knowledge sharing (Orabi, 2016: 9) so that transformational leaders can bring change and innovation as well as foster and increase work motivation in an organizational environment.

Transformational leadership style according to experts is to have four dimensions consisting of: (1) ideal influence, charismatic, providing vision and mission to achieve respect and trust, (2) motivational inspiration, communicating the intended expectations and expressing the importance of goals in a simple way; (3) intellectual simulations, encouraging intelligence and rationality and being careful in solving problems; and (4) individual consideration (Voon et al., 2011); (Ahmad et al., 2014); and (Aydin et al., 2013). Based on the above framework, there is a direct influence on transformational leadership style on productivity, reward systems, communication, and motivation, and there is an indirect influence on transformational leadership style on the productivity of lecturers to produce international scientific work in private universities (PTS) through motivation.

Understanding communication as an independent variable in this study can be interpreted as follows: transferring information or messages that contain relational components (affective) and tasks (content) from one person to another or to a group effectively in order to increase the motivation and productivity of lecturers in Higher Education Private to produce international scientific works. With several indicators adopted from (Abdussamad, 2015) with several 
indicators as follows: (1) Openness; (2) Empathy; (3) Support; (4) Positive feelings; (5) Similarity; (6) Performance oriented. Effect of direct communication on productivity Organizations can run successfully, only if effective organizational communication takes place (Sadia, Salleh, Kadir \& Sanif, 2016: 34). In this context, (Muda et al., 2014) stated that the importance of communication to be applied within the organization, transferring information or messages from one person to another or to a group by leaders (Luthra \& Dahiya, 2015) in order to influence the bottom-line, increase employee productivity (Ajala, 2012)

.Effect of direct communication on motivation. According to (Luthra \& Dahiya, 2015), communication means transferring information or messages from one person to another or to a group and effective leadership communication, transferring messages keeping in mind the recipient's understanding and ability and ensuring that the recipient will be able to find the right meaning of message or information passed on to him. According to (Nabi, Foysol, \& Adnan, 2017), business communication is a very important element in business organizations because of the need for interaction and understanding of management relations with employees so that it will have an impact on organizational performance and organizational results. According to (Luthfie et al., 2017), a good organization can be achieved if there is a good communication climate, showing harmonization of communication between leaders and members, between superiors and subordinates, between leaders, or among members will affect the performance of company employees (Gusfa et al., 2017) and employee motivation (Luthfie et al., 2017).

Then, the effect of communication indirectly on productivity through motivation. Trustbased communication in organizations can build a more conducive work environment and the estuary is that employees feel motivated such as: self-confidence, working in coordination and coordination resulting in employee performance to achieve the targets given both individual targets and team targets (Luthra \& Dahiya, 2015) how to communicate effectively with each other can increase employee productivity through motivation (Ajala, 2012); (Luthra \& Dahiya, 2015)

Based on the above framework, there is a positive direct effect of communication on productivity, and motivation and an indirect effect on the productivity of lecturers to produce international scientific article in private universities through motivation. Understanding motivation as an independent variable and also as a moderating variable in this study can be interpreted as a factor that drives the mentality of lecturers to produce and increase the productivity of international scientific article in Private Universities. In this case, several indicators were adopted from (Olusadum \& Anulika, 2018); (Mohamud et al., 2017); (Al Doghan \& Albar, 2015); (Bao \& Nizam, 2015); (Onanda, 2015); (Osabiya, 2015); and (Robescu \& Iancu, 2016); (Upev et al., 2015). as follows: (1) Mission, vision, and goals of the organization; (2) Skill level; (3) Knowledge of completing tasks; (4) Feelings and emotions; (5) Facilitating; (6) Management behavior; (7) Quality of work life; (8) Technician / recognition; (9) Employee involvement; (10) Conditions of service.

The effect of motivation directly on productivity - Each organization focuses on what must be done to achieve high and sustainable levels of productivity or performance by paying special attention to how individuals can be motivated properly through means such as incentives, rewards, leadership, etc. ( Osabiya, 2015); (Said, Zaidee, Zahari, Ali; \& Salleh, 2017: 632). Therefore, efforts to increase employee motivation as human resources (HR) are the most strategic element (Natural, 2015) to achieve the organization's mission, vision, and goals (Olusadum \& Anulika, 2018) because there is a relationship between motivation and productivity/ performance (Robescu \& Iancu, 2016). Based on the above frame of mind, it is suspected that there is an influence of motivation on productivity to produce international scientific work in private universities. 


\section{RESEARCH METHOD}

Researchers use quantitative methods to understand more deeply related to the problems that exist in the formulation of the problems that have been described in this study. Therefore, this study requires statistical testing using structural equation modeling (SEM) because SEM is a statistical technique used to construct and test statistical models that are usually in the form of causal models which include the affirming aspects of factor analysis, path analysis and regression which can be considered as case specific. Then, the population has a very important role in a study because according to Sujarweni (2015) the population is the whole amount consisting of objects or subjects that have certain qualities and characteristics determined by researchers to be studied and then conclusions drawn.

Thus, the study population was all lecturers who worked at Trisakti University, Bina Nusantara University, and Tarumanagara University ,. Furthermore, as many as 600 questionnaire packages were distributed proportionally to Trisakti University, Bina Nusantara University, and Tarumanagara University and researchers worked with the university for a period of three months, September, October, and December 2019) to distribute questionnaire pacts. Researchers have distributed 600 questionnaire packages and around 360 questionnaires returned to researchers and 310 questionnaire packages that can be used, can be analyzed further. According to (HairJr, Hult, Ringle, \& Sage, 2013), the minimum sample size appropriate for use in the Structural Equation Modeling (SEM) technique should be based on the complexity of the model and the characteristics of the measurement model, namely: if the number of constructs is 7 (seven) constructs or less, with the level of correlation between indicators 0.5 the minimum number of samples is 150 respondents; the more the number of constructs and the lower the correlation level the minimum number of samples increases.

\section{RESULT AND DISCUSSION}

\section{Constellation of the Direct Effect Model}

Positive direct effect of the reward system $\left(\mathrm{X}_{1}\right)$, transformational leadership style $\left(\mathrm{X}_{2}\right)$, communication $\left(\mathrm{X}_{3}\right)$, and motivation $\left(\mathrm{X}_{4}\right)$ on productivity $(\mathrm{Y})$.

Full Structural Model Test Results (SEM) - Full Structural Model Analysis (Full Model) is performed after an analysis of the construct variable in measuring or forming latent variables that are tested with confirmatory factor analysis. Structural analysis of equation modeling in full models must meet the evaluation criteria of a model, SEM Model Evaluation Criteria including Discrimnant validity, Multivariate Normality, data outliers, Multicolinearity and singularity and goodnest of fit models. Full model SEM calculation is done by using AMOS SPSS 23 software. Based on the results of the full SEM model test above, it can be seen that there are several observable variables or constructs that do not meet the requirements to be used in the calculation of cfa models on each variable and the goodnest of fit criteria in a research model. not fulfilled so that the model is respected by removing the observed variable / construct from the cfa model of each variable. The results of the re-verification of the research model can be seen in the following Amos output: 


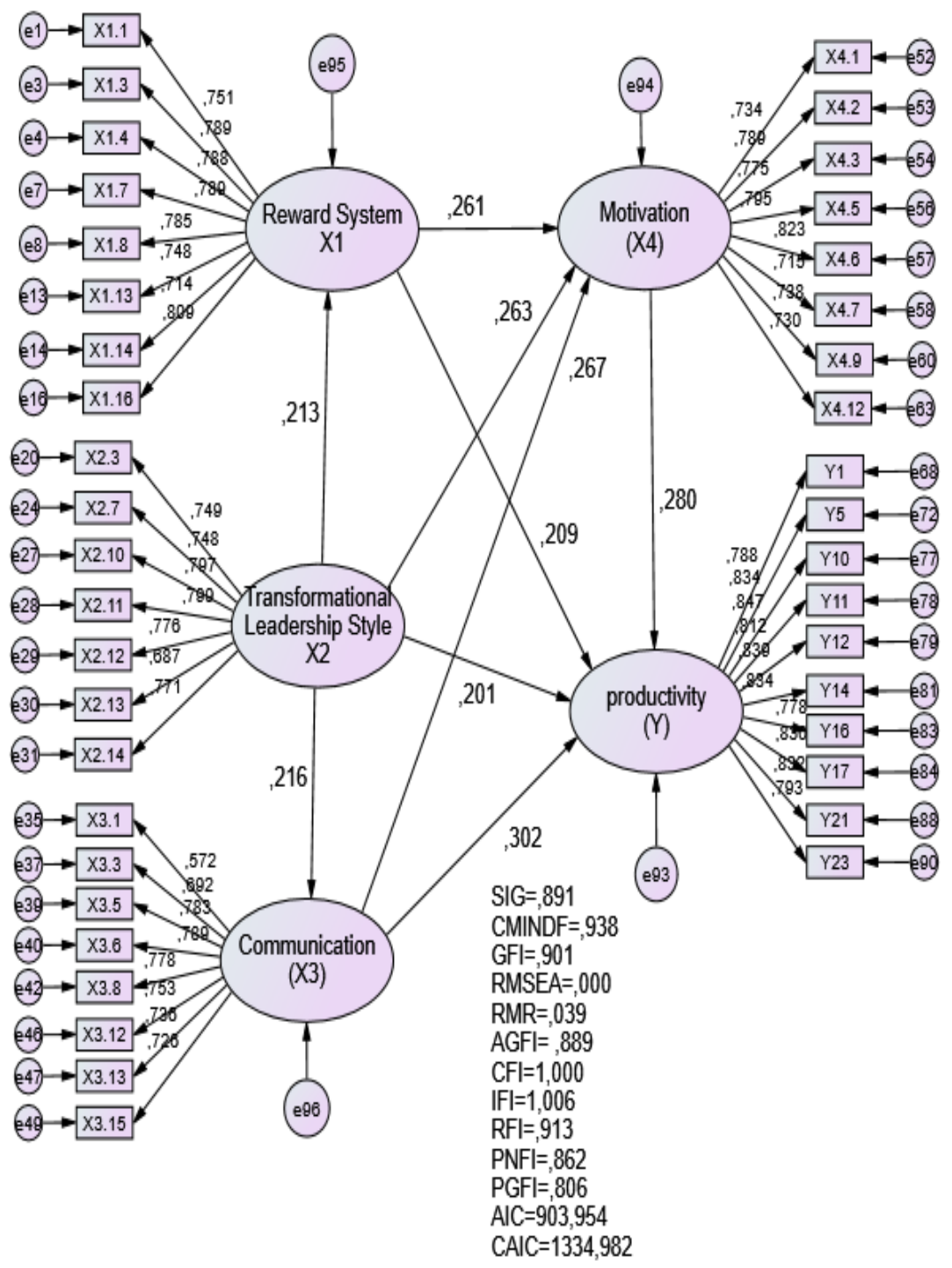

Figure 3. Final Standardized Solutiton SEM Model Source: Research Results

Table 3 : Path Coefficient and CR (t - value )

\begin{tabular}{|c|c|c|c|c|c|c|}
\hline Endogenous variables & exogenous variables & $\begin{array}{c}\text { Std } \\
\text { Estimate }\end{array}$ & $\begin{array}{c}\text { Unstd } \\
\text { Estimate }\end{array}$ & S.E. & C.R. & $\mathbf{P}$ \\
\hline Productivity_Y & $<---$ Reward_System_X1 & 0,209 & 0,214 & 0,054 & 3,981 & \\
\hline Productivity_Y & $<---$ Transformational_LS_X2 & 0,201 & 0,206 & 0,056 & 3,715 & $* * *$ \\
\hline Productivity_Y & $<---$ Communication_X3 & 0,302 & 0,415 & 0,081 & 5,132 & $* * *$ \\
\hline Productivity_Y & $<---$ Motivation_X4 & 0,280 & 0,298 & 0,064 & 4,663 & $* * *$ \\
\hline Reward_System_X1 & $<---$ Transformational LS_X2 & 0,213 & 0,214 & 0,063 & 3,39 & $* * *$ \\
\hline Communication_X3 & $<---$ Transformational LS X2 & 0,216 & 0,161 & 0,049 & 3,326 & $* * *$ \\
\hline Motivation X4 & $<---$ Reward System X1 & 0,261 & 0,250 & 0,056 & 4,45 & $* * *$ \\
\hline Motivation X4 & $<---$ Transformational LS X2 & 0,263 & 0,254 & 0,058 & 4,347 & $k * *$ \\
\hline Motivation_X4 & $<---$ Communication_X3 & 0,267 & 0,344 & 0,080 & 4,309 & $* * *$ \\
\hline
\end{tabular}

To test the significance of the direct effect path coefficients can be seen in table 3, Path Coefficients and C.R. (t-value) as follows::

Based on the correlation variables and square root AVE in table 3 value of the Reward_System_ latent variable with other latent variables of 0.209, 0.206; 0.364, 0.407 smaller than the value of the square root Average Variance Extracted ( $\sqrt{ }$ AVE) Reward_System $\left(\mathrm{X}_{1}\right)$ of 0.772; the correlation value of the latent variable of Transformational Leadership Style $\left(\mathrm{X}_{2}\right)$ with other latent variables of $0,209,0,213 ; 0.371,0.409$; smaller than the value of the square root 
Average Variance Extracted ( $\mathrm{A}$ VE) Transformational Leadership Style $\left(\mathrm{X}_{2}\right)$ of 0.762 ; the correlation value of the latent variable Communication $\left(\mathrm{X}_{3}\right)$ with other latent variables is 0.206; $0.213 ; 0,371 ; 0,484$, smaller than the Average Variance Extracted ( $\sqrt{ }$ AVE) Communication $\left(\mathrm{X}_{3}\right)$ quadratic value of 0.732 ; and the correlation value of latent variables Motivation $\left(\mathrm{X}_{4}\right)$ with other latent variables of $0.364 ; .371 ; 0.371 ; 0.371 ; 0.563$, smaller than the Square Variable Extracted ( $\sqrt{ }$ AVE) Motivation $\left(\mathrm{X}_{4}\right)$ value of 0.766 , and the correlation value of the latent variable Productivity (Y) with other latent variables of $0.407 ; 0.409 ; 0484 ; 0.536$ is smaller than the Average Variance Extracted ( $\sqrt{ }$ AVE) Productivity $(\mathrm{Y})$ value of squares of 0.823 . This can be interpreted that each latent variable has good discriminant validity, because all correlation values between latent are lower than the Square Variable Extracted ( $\sqrt{\mathrm{AVE}}$ ) quadratic value on each latent variable. Thus it can be concluded that all latent variables in this study are quite unique and able to capture the measured phenomenon.

Goodness of Fit (GOF) Structural Equation Model : Structural Equation Model Goodness of Fit (GOF) - Test suitability of the model is expected to accept the null hypothesis. In SEM the test is carried out by using a number of Goodness of Fit Test (GOF). Fit Test Model or Goodness of Fit (GOF) aims to measure the suitability of research data with research models in other words measure the suitability of observational or real input (covariance/correlation matrix) with the proposed model predictions. Fit Test Model - Full Fit SEM Model can be seen in the following table:

Table 4 : Goodness Of Fit Criteria

\begin{tabular}{|c|c|c|c|}
\hline \multicolumn{4}{|c|}{ Absolut Fit Measure } \\
\hline Goodness-of-Fit & Cut-off Value & Result & Description \\
\hline p-value (Sig.) & $>0,05$ & 0,891 & Good fit \\
\hline Chi-Squareldf & $\leq 3$ & 0,938 & Good fit \\
\hline GFI(Goodness of Fit) & $\geq 0,90$ & 0,901 & Good fit \\
\hline RMSEA(Root Mean square Error of Approximation) & $\leq 0,08$ & 0,000 & Good fit \\
\hline RMR (Root Mean Square Residual) & $\leq 0,05$ & 0,039 & Good fit \\
\hline \multicolumn{4}{|c|}{ Incremental Fit Measure } \\
\hline AGFI(Adjusted Goodness of Fit Index) & $\geq 0,90$ & 0,889 & Marginal fit \\
\hline CFI (Comparative Fit Index) & $\geq 0,90$ & 1,000 & Good fit \\
\hline Incremental Fit Index (IFI) & $\geq 0,90$ & 1,006 & Good fit \\
\hline Relative Fit Index (RFI) & $\geq 0,95$ & 0,913 & Marginal fit \\
\hline \multicolumn{4}{|c|}{ Parsimonious Fit Measure } \\
\hline PNFI (Parsimonious Normed Fit Index) & value closer to zero & 0,862 & Marginal fit \\
\hline PGFI (Parsimonious Goodness Of Fit Index) & value closer to 1 & 0,806 & Good fit \\
\hline AIC (Akaike Information Criterion) & $<1722,000$ & 903,954 & Good fit \\
\hline CAIC ( Consistent Akaike Information Criter & $<5800,189$ & 1334,954 & Good fit \\
\hline
\end{tabular}

Based on table 4, the output of Fit Test Model - Full Fit SEM Model is mostly model fit criteria in the good fit category. Meanwhile (Hair, et al, 2010 in Latan, 2012: 49) states that 4 - 5 goodness of fit criteria are considered sufficient to assess the feasibility of a model, provided that each criterion of goodness of fit is absolute fit indices, incremental fit indices and parsimony indices are represented.

Thus it can be concluded that the goodness of fit test of the full Model SEM model can be accepted in other words there is no significant difference between the covariance matrix of the observed variable variable (construct) and the covariance matrix of the specified model. This shows that the structural equation produced by the research model can be used to explain the influence between exogenous variables and their endogenous variables.

\section{Hypothesis Testing}

Hypothesis testing using the Structural Equation Modeling (SEM) technique aims to determine whether there is a direct or indirect effect. The direct effect (direct effect) is the influence of the independent variable (exogenous) on the dependent variable (endogenous) while the indirect effect (indirect effect) is the influence of the independent variable (exogenous) on the dependent variable (exogenous)) through other variables or moderating variables. Testing the direct effect on the research model is done by looking at the value of the path coefficient on each path of the research hypothesis and proceed with the t test (C.R: Critical Ratio) to determine the value of the path coefficient or value of the influence in the significant category. While testing the indirect effect on the research model is done by looking at the value of the path coefficient on 
each path of the research hypothesis and followed by the Sobel Test to find out the value of the path coefficient or the value of the influence in the significant category. Testing the indirect effect or testing the effect of independent variables on the dependent variable through mediating variables. The Sobel test is used to determine whether a variable carries (or mediates) the influence of an independent variable on the dependent variable as for the sobel formula.

The first hypothesis, there is a positive direct effect on the Reward System $\left(\mathrm{X}_{1}\right)$ on Productivity (Y). From the calculation of Structural Equation Modeling the direct effect of the Reward System () on Productivity (Y), the path coefficient value of $\mathrm{py}_{1}$ is 0.209 and CR (tcount) is 3.981. Because the value of CR $(3.981) \geq 1.96$, then reject $\mathrm{H}_{0}$, accept $\mathrm{H}_{1}$ and can be interpreted that there is a direct effect of the positive Reward System $\left(\mathrm{X}_{1}\right)$ on Productivity (Y). The results of the hypothesis analysis provide the finding that the Reward System $\left(\mathrm{X}_{1}\right)$ has a direct positive effect on Productivity (Y). This can be interpreted that the better the Reward System will lead to increased Productivity and vice versa, the worse the Reward System will cause a decline in Productivity.

The second hypothesis, there is a positive direct effect on the Transformational Leadership Style $\left(\mathrm{X}_{2}\right)$ on Productivity (Y) From the results of the calculation of the Structural equation Modeling the direct effect of the Transformational Leadership Style $\left(\mathrm{X}_{2}\right)$ on Productivity $(\mathrm{Y})$, the path coefficient value of $\mathrm{py}_{2}$ is 0.201 and $\mathrm{CR}$ (t-count) ) amounted to 3,715. Because the value of $\mathrm{CR}(3,715) \geq 1.96$, then reject $\mathrm{H}_{0}$, accept $\mathrm{H}_{1}$ and can be interpreted that there is a positive direct effect on the Transformational Leadership Style $\left(\mathrm{X}_{2}\right)$ on Productivity (Y). The results of hypothesis analysis provide findings that the Transformational Leadership Style $\left(\mathrm{X}_{2}\right)$ has a direct positive effect on Productivity (Y). This can be interpreted as getting better. The Transformational Leadership Style causes productivity to increase and vice versa, the worse the Transformational Leadership Style will cause the decline in Productivity.

The third hypothesis, there is a positive direct effect of Communication $\left(\mathrm{X}_{3}\right)$ on Productivity (Y). From the calculation results of Structural Equation Modeling the direct influence of Communication $\left(\mathrm{X}_{3}\right)$ on Productivity $(\mathrm{Y})$ py $_{3}$ path coefficient value is 0.302 and $\mathrm{CR}$ ( $t$-count) is 5.132. Because the value of $\mathrm{CR}(5.132) \geq 1.96$, then reject $\mathrm{H}_{0}$, accept $\mathrm{H}_{1}$ and can be interpreted that there is a positive direct effect of Communication $\left(\mathrm{X}_{3}\right)$ on Productivity (Y). Hypothesis analysis results provide findings that Communication $\left(\mathrm{X}_{3}\right)$ has a direct positive effect on Productivity $(\mathrm{Y})$. This can be interpreted as higher Communication $\left(\mathrm{X}_{3}\right)$ will cause increased Productivity and vice versa lower communication $\left(\mathrm{X}_{3}\right)$ will cause a decrease in Productivity and vice versa is interpreted increasingly Bad communication will cause a decline in productivity.

The fourth hypothesis, there is a positive direct effect of Motivation $\left(\mathrm{X}_{4}\right)$ on Productivity (Y). From the calculation of Structural Equation Modeling the direct influence of Motivation (X4) on Productivity (Y), the path coefficient value $\mathrm{py}_{4}$ is 0.280 and $\mathrm{CR}$ (t-count) is 4.663. Because the value of $\mathrm{CR}(4.663) \geq 1.96$, then reject $\mathrm{H}_{0}$, and accept $\mathrm{H}_{1}$ and can be interpreted that there is a direct positive effect on Motivation $\left(\mathrm{X}_{4}\right)$ on Productivity $(\mathrm{Y})$. The results of hypothesis analysis provide findings that Motivation $\left(\mathrm{X}_{4}\right)$ has a direct positive effect on Productivity (Y). This can be interpreted as higher Motivation $\left(\mathrm{X}_{4}\right)$ will cause increased Productivity and vice versa Seamkin low Motivation will lead to a decline in Productivity and vice versa means better Motivation will lead to increased Productivity.

The fifth hypothesis, there is a positive direct effect of the Transformational Leadership Style $\left(\mathrm{X}_{2}\right)$ on the Reward System $\left(\mathrm{X}_{1}\right)$. From the calculation results of Structural Equation Modeling the direct influence of Transformational Leadership Style $\left(\mathrm{X}_{2}\right)$ on the Reward System $\left(\mathrm{X}_{1}\right)$, the path coefficient value $\mathrm{p}_{12}$ is 0.213 and $\mathrm{CR}$ (t-count) is 3.390 . Because the value of CR (3.390) $\geq 1.96$, then reject $\mathrm{H}_{0}$, accept $\mathrm{H}_{1}$ and can be interpreted that there is a direct influence on the Positive Transformational Leadership Style $\left(\mathrm{X}_{2}\right)$ on the Reward System $\left(\mathrm{X}_{1}\right)$. The results of hypothesis analysis provide the finding that the Transformational Leadership Style $\left(\mathrm{X}_{2}\right)$ has a direct positive effect on the Reward System $\left(\mathrm{X}_{1}\right)$.

The sixth hypothesis, there is a positive direct effect on the Transformational Leadership Style $\left(\mathrm{X}_{2}\right)$ on Communication $\left(\mathrm{X}_{3}\right)$. From the calculation of Structural Equation Modeling the direct influence of Transformational Leadership Style $\left(\mathrm{X}_{2}\right)$ on Communication $\left(\mathrm{X}_{3}\right)$, the path coefficient value of $\mathrm{p}_{32}$ is 0.216 and CR (t-count) is 3.326. Because the value of CR (3.326) $\geq$ 
1.96, then reject $\mathrm{H}_{0}$, accept $\mathrm{H}_{1}$ and can be interpreted that there is a direct influence on the Positive Transformational Leadership Style $\left(\mathrm{X}_{2}\right)$ on Communication $\left(\mathrm{X}_{3}\right)$. The results of hypothesis analysis provide the finding that the Transformational Leadership Style $\left(\mathrm{X}_{2}\right)$ has a direct positive effect on Communication $\left(\mathrm{X}_{3}\right)$. This can be interpreted the better the Transformational Leadership Style causes good Communication and vice versa the worse the Transformational Leadership Style causes poor Communication.

The seventh hypothesis, there is a positive direct effect on the Transformational Leadership Style $\left(\mathrm{X}_{2}\right)$ on Motivation $\left(\mathrm{X}_{4}\right)$. From the calculation of Structural Equation Modeling the direct effect of the Transformational Leadership Style $\left(\mathrm{X}_{2}\right)$ on Motivation $\left(\mathrm{X}_{4}\right)$, the path coefficient $\mathrm{p}_{42}$ is 0.263 and $\mathrm{CR}$ (t-count) is 4.347. Because the value of CR $(4.347) \geq 1.96$, then reject $\mathrm{H}_{0}$, accept $\mathrm{H}_{1}$ and can be interpreted that there is a positive direct effect on the Transformational Leadership Style $\left(\mathrm{X}_{2}\right)$ on Motivation $\left(\mathrm{X}_{4}\right)$. The results of hypothesis analysis provide findings that the Transformational Leadership Style $\left(\mathrm{X}_{2}\right)$ has a direct positive effect on Productivity Motivation (X4). This can be interpreted the better the Transformational Leadership Style will lead to increased motivation The worse the Transformational Leadership Style will cause a decline in Motivation.

The eighth hypothesis, there is a positive direct effect on the Reward System $\left(\mathrm{X}_{1}\right)$ on Motivation $\left(\mathrm{X}_{4}\right)$. From the results of the calculation of Structural Equation Modeling the direct effect of the Reward System $\left(\mathrm{X}_{1}\right)$ on Motivation $\left(\mathrm{X}_{4}\right)$ path coefficient value $\mathrm{p}_{41}$ of 0.261 and CR ( $\mathrm{t}$-count) of 4.450. Because the value of CR (4.450) $\geq 1.96$, then accept $\mathrm{H}_{0}$, reject $\mathrm{H}_{1}$ and can be interpreted that there is a positive direct effect on the Reward System $\left(\mathrm{X}_{1}\right)$ on Motivation $\left(\mathrm{X}_{4}\right)$. The results of hypothesis analysis provide findings that the Reward System $\left(\mathrm{X}_{1}\right)$ has a direct positive effect on motivation $\left(\mathrm{X}_{4}\right)$ which can be interpreted as getting better. A good reward system will cause an increase in motivation. A lower reward system will cause a decline in motivation.

The ninth hypothesis there is a positive direct effect of Communication $\left(\mathrm{X}_{3}\right)$ on Motivation $\left(\mathrm{X}_{4}\right)$. From the results of the calculation of Structural Equation Modeling the direct influence of Communication $\left(\mathrm{X}_{3}\right)$ on Motivation $\left(\mathrm{X}_{4}\right)$ the path coefficient value $\mathrm{p}_{43}$ of 0.267 and $\mathrm{CR}$ (t-count) of 4.309. Because the value of $\mathrm{CR}(4.309) \geq 1.96$, then accept $\mathrm{H}_{0}$, reject $\mathrm{H}_{1}$ and can be interpreted that there is a positive direct effect of Communication $\left(\mathrm{X}_{3}\right)$ on Motivation $\left(\mathrm{X}_{4}\right)$. The results of the fifth hypothesis analysis provide findings that Communication $\left(\mathrm{X}_{3}\right)$ has a direct positive effect on Motivation $\left(\mathrm{X}_{4}\right)$. This can be interpreted as better Communication $\left(\mathrm{X}_{3}\right)$ will cause increased Motivation $\left(\mathrm{X}_{4}\right)$ and lower Communication $\left(\mathrm{X}_{3}\right)$ will cause a decrease in Motivation $\left(\mathrm{X}_{4}\right)$.

10. Hypothesis tenth, there is a positive indirect effect of the Reward System $\left(\mathrm{X}_{1}\right)$ on Productivity $(\mathrm{Y})$ through Motivation $\left(\mathrm{X}_{4}\right)$. Path coefficient (mediation) the indirect effect of the Rewards System on Productivity through Motivation is $\beta_{41} \times \beta_{\mathrm{y} 3}=(0.261 \times 0.280)=0.0731$ with a $\mathrm{z}$ value (Sobel Test) of (3.222). Because the value of $\mathrm{Z}$ (3.222) is greater than 1.96, it can be concluded that the indirect effect of the Reward System $\left(\mathrm{X}_{1}\right)$ on Productivity (Y) through Motivation $\left(\mathrm{X}_{4}\right)$ is positive and significant. The sobel test calculation results are obtained by using the online sobel test calculator.

The eleventh hypothesis, there is a positive indirect effect on the Transformational Leadership Style $\left(\mathrm{X}_{2}\right)$ on Productivity $(\mathrm{Y})$ through Motivation $\left(\mathrm{X}_{4}\right)$. Path coefficient (mediation) the indirect effect of Transformational Leadership Style on Productivity through Motivation of $\beta_{42} \times \beta_{\mathrm{y} 4}=(0.263 \times 0.280)=0.0736$ with a $\mathrm{z}$ value (Sobel Test) of (3.190). Because the value of $\mathrm{Z}$ (3.190) is greater than 1.96, it can be concluded that the indirect effect of the Transformational Leadership Style $\left(\mathrm{X}_{2}\right)$ on Productivity $(\mathrm{Y})$ through Motivation $\left(\mathrm{X}_{4}\right)$ is positive and significant. The sobel test calculation results are obtained by using the online sobel test calculator.

The twelfth hypothesis, there is an indirect effect of Positive Communication $\left(\mathrm{X}_{3}\right)$ on Productivity (Y) through Motivation $\left(\mathrm{X}_{4}\right)$. Path coefficient (mediation) the indirect effect of Communication on Productivity through Motivation of $\beta_{43} X \beta_{\mathrm{y} 4}=(0.267 \times 0.280)=0.0748$ with $\mathrm{Z}$ value (Sobel Test) of (3.159). Because the value of $\mathrm{Z}$ (3.159) is greater than 1.96, it can be concluded that the indirect effect of Communication $\left(\mathrm{X}_{3}\right)$ on Productivity (Y) through Motivation $\left(\mathrm{X}_{4}\right)$ is positive and significant. 


\section{Discussion}

\section{The positive direct effect of the Reward System $\left(\mathrm{X}_{1}\right)$ on Productivity $(\mathrm{Y})$}

Hypothesis 1 is supported by the results of previous studies it can be said that the reward system will be more effectively used in conjunction with the productivity of lecturers in private universities to produce and increase the productivity of international scientific work as an element that influences. This research also strengthens the findings of research (Kim \& Ployhart, 2014; Upev, Chorun, \& Idachaba, 2015) (Ibrar \& Khan, 2015 ); (Upev et al., 2015); (Akafo \& Boateng, 2015); (Eshak et al., 2016); (Yamoah, 2013); and (Aithal, 2016) which states that a reward or reward system (Wasiu \& Adebajo, 2014) is a reward given objectively through fair treatment (Fernandez \& Pitts, 2011) by management (Ndungu, 2017) in accordance with contributions, skills and competencies as an encouragement to have a positive attitude at work to increase motivation and productivity.

\section{The positive direct effect of the Transformational Leadership Style $\left(\mathrm{X}_{2}\right)$ on Productivity} (Y)

Hypothesis 2 is supported by the results of previous studies it can be said that the Transformational Leadership Style will be more effectively used in relation to the productivity of lecturers in Private Universities to produce and improve productivity of international scientific work as an influencing element. The results of the hypothesis analysis provide findings that the Transformational Leadership Style $\left(\mathrm{X}_{2}\right)$ has a direct positive effect on Productivity (Y). This study also strengthens the findings of research ((Kim \& Ployhart, 2014; Upev, Chorun, \& Idachaba, 2015; Iqbal et al., 2015) which states that organizational success depends on the Transframational Leadership Style $\left(\mathrm{X}_{2}\right)$, which is an innovative, productive and innovative leader support (Bushra et al., 2011), share knowledge of Orabi (2016: 9), bring change, innovation, foster and increase work motivation in the organizational environment to achieve both personal work targets and team targets (Luthra \& Dahiya, 2015; Veliu et al., 2017); (Voon et al., 2011); (Veliu et al., 2017); (Ahmad et al., 2014); and (Aydin et al., 2013).

\section{The positive direct effect of Communication $\left(\mathbf{X}_{3}\right)$ on Productivity ( $\left.\mathbf{Y}\right)$}

Hypothesis 3 is supported by the results of previous studies it can be said that Communication will be more effective and very significant used in relation to the productivity of lecturers in Private Universities to produce and increase work productivity international science as an influencing element. This research also strengthens the findings of research (Kim \& Ployhart, 2014; Upev, Chorun, \& Idachaba, 2015; Sadia, Salleh, Kadir \& Sanif, 2016: 34) which states that organizations can run successfully, only if organizational communication is effective, i.e. transferring information or messages from one person to another or to a group and leadership communication (Luthra \& Dahiya, 2015) applied within the organization means less complaining and more work done, and this eliminates confusion and frees up wasted time that should have been spent on explanation (Ajala, 2012) so that it can influence the bottom-line through the communication climate (Luthfie, Hubeis, Saleh, \& Ginting, 2017) that is good in order to increase employee productivity (Muda et al., 2014; Gusfa et al., 2017).

\section{Positive direct effect of Motivation $\left(\mathrm{X}_{4}\right)$ on Productivity $(\mathrm{Y})$}

Based on the results of research on this hypothesis 4 , Motivation $\left(\mathrm{X}_{4}\right)$ will be more effectively used in conjunction with Productivity (Y), which is to increase the productivity of lecturers at Private Universities to produce international scientific work as an influencing element. This research also strengthens the findings of the study and is supported by the results of previous studies (Kim \& Ployhart, 2014; Upev, Chorun, \& Idachaba, 2015). 
The direct positive effect of the Transformational Leadership Style $\left(\mathrm{X}_{2}\right)$ on the Reward $\operatorname{System}\left(\mathbf{X}_{1}\right)$

Based on the results of research on this hypothesis 5 , and supported by the results of previous studies it can be said that the Transformational Leadership Style $\left(\mathrm{X}_{2}\right)$ will be more effectively used in conjunction with the Reward System $\left(\mathrm{X}_{1}\right)$ given to produce and increase the productivity of lecturers producing international scientific work. in private universities is an element that influences. This study also strengthens the findings of research (Kim \& Ployhart, 2014; Upev, Chorun, \& Idachaba, 2015; Al Doghan \& Albar, 2015) which states that the leadership encouragement and reward system in the form of engineering or recognition of employee work or rewards in the form of money and nominal wages as individual considerations or Individual Consideration (Ahmad et al., 2014) must be designed and implemented correctly in the organization (Bao \& Nizam, 2015) will be able to motivate employees to achieve the organization's vision and goals (Gathii \& K'Obonyo , 2017) so they have a positive attitude at work, leads to job satisfaction, and can increase productivity / performance.

\section{The positive direct influence of Transformational Leadership Style $\left(\mathbf{X}_{2}\right)$ on Communication} $\left(\mathbf{X}_{3}\right)$

Based on the results of this research on hypothesis 6, the Transformational Leadership Style $\left(\mathrm{X}_{2}\right)$ has a direct positive effect on Communication $\left(\mathrm{X}_{3}\right)$ will be more effectively used in relation to the productivity of lecturers in private universities to produce and increase the productivity of international scientific work as an influencing element. This research also strengthens the findings of the study and is supported by the results of previous studies (Kim \& Ployhart, 2014; Upev, Chorun, \& Idachaba, 2015).

\section{The positive direct influence of Transformational Leadership Style $\left(\mathbf{X}_{2}\right)$ on Motivation $\left(\mathbf{X}_{4}\right)$}

Based on the results of this research on hypothesis 7, Transformational Leadership Style $\left(\mathrm{X}_{2}\right)$ has a direct positive effect on Motivation $\left(\mathrm{X}_{4}\right)$ will be more effectively used in relation to the productivity of lecturers in the College Higher Private to produce and increase productivity of international scientific work as an element of influence. This research also strengthens the findings of the study and is supported by the results of previous studies (Kim \& Ployhart, 2014; Upev, Chorun, \& Idachaba, 2015).

\section{The positive direct effect of the Reward System $\left(\mathbf{X}_{1}\right)$ on Motivation $\left(\mathbf{X}_{4}\right)$}

Based on the results of this research on hypothesis 8, the Reward System $\left(\mathrm{X}_{1}\right)$ given to employees will cause increased Motivation $\left(\mathrm{X}_{4}\right)$ to be more effectively used in relation to lecturer productivity in private universities to produce and increase the productivity of international scientific work as an influencing element. This research also strengthens the findings of the research and is supported by the results of previous studies (Kim \& Ployhart, 2014; Upev, Chorun, \& Idachaba, 2015).

\section{The positive direct effect of Communication $\left(\mathbf{X}_{3}\right)$ on Motivation $\left(\mathbf{X}_{4}\right)$}

Based on the results of research on this hypothesis 9 , Motivation $\left(\mathrm{X}_{4}\right)$ for the productivity of lecturers in private universities to produce and improve international scientific work as an element of influence. This research also strengthens the findings of the research and is supported by the results of previous studies and supported by the results of previous studies (Kim \& Ployhart, 2014; Upev, Chorun, \& Idachaba, 2015).

\section{The indirect effect of the Rewards System $\left(\mathbf{X}_{1}\right)$ on Productivity $(Y)$ through Motivation $\left(\mathbf{X}_{4}\right)$}

The calculation result of the sobel test is obtained by using the online sobel test calculator. Based on the results of research on this hypothesis 10, that the path coefficient (mediation) indirect effect of the Reward System $\left(\mathrm{X}_{1}\right)$ on Productivity $(\mathrm{Y})$ through Motivation $\left(\mathrm{X}_{4}\right)$ is positive and significant. This research also strengthens the findings of the research and is supported by the results of previous studies (Kim \& Ployhart, 2014; Upev, Chorun, \& Idachaba, 2015). 
The indirect effect of the Transformational Leadership Style $\left(\mathrm{X}_{2}\right)$ on Productivity (Y) through Motivation $\left(\mathbf{X}_{4}\right)$

The sobel test calculation results are obtained using the online sobel test calculator. Based on the results of this research on hypothesis 11 , that the path coefficient (mediation) the indirect effect of the Transformational Leadership Style $\left(\mathrm{X}_{2}\right)$ on Productivity (Y) through Motivation $\left(\mathrm{X}_{4}\right)$ is positive and significant. This study also reinforces the findings of the study and is supported by the results previous studies (Kim \& Ployhart, 2014; Upev, Chorun, \& Idachaba, 2015); (Voon et al., 2011); (Ahmad et al., 2014); and (Aydin et al., 2013).

\section{The indirect effect of Communication $\left(X_{3}\right)$ on Productivity $(Y)$ through Motivation $\left(X_{4}\right)$ is positive and significant.}

The results of the calculation of the sobel test are obtained by using the online sobel test calculator. Based on the results of research on this hypothesis 12, that the path coefficient (mediation) the indirect effect of Communication $\left(\mathrm{X}_{3}\right)$ on Productivity $(\mathrm{Y})$ through Motivation $\left(\mathrm{X}_{4}\right)$ is positive and significant. This research also strengthens the findings of the study and is supported by the results of previous studies. (Kim \& Ployhart, 2014; Upev, Chorun, \& Idachaba, 2015).

\section{CONCLUSION AND RECOMMENDATION}

From the results of the calculation of Structural Equation Modeling positive and significant direct influence, the findings of the significance of this study are proven Communication variable $\left(\mathrm{X}_{3}\right)$ has the most dominant influence on Productivity $(\mathrm{Y})$ with $\mathrm{py}_{3}$ path coefficient of 0.302 and CR (t-count) of 5.132. Therefore, it is recommended that leaders in State Universities and Private Universities can adopt the findings of this research to change the mind set, lecturers as scientists to be able to actualize their thoughts, scientific ideas, and publish them in the form of scientific works both national and international standards as an effort to expand knowledge and open new avenues of science and technology. Then, based on the results of the calculation of Structural Equation Modeling (SEM) direct influence and indirect influence, it is recommended to leaders as decision makers in private universities to increase the productivity of lecturers producing international scientific work is a strategic agenda and important to be implemented as follows:

Positive direct influence and significant: Motivation $\left(\mathrm{X}_{4}\right)$ will be more effectively used in conjunction with Productivity ( $\mathrm{Y}$ ) as an influencing element with a py 4 path coefficient of 0.280 , $\mathrm{CR}$ (t-count) of 4.663; and Reward system $\left(\mathrm{X}_{1}\right)$ with a py 1 path coefficient of 0.209 , CR ( $\mathrm{t}-$ count) ) amounted to 3,981, and the Transformational Leadership Style $\left(\mathrm{X}_{2}\right)$ with a path coefficient value of $\mathrm{py}_{2}$ of 0.201 , CR (t-count) of 3.715 .

Positive and significant indirect effect, i.e. Motivation $\left(\mathrm{X}_{4}\right)$ as a moderating variable and obtained path coefficient (mediation) as a non-influence immediately positive and significant Reward System $\left(X_{1}\right)$ to Productivity (Y) through Motivation $\left(X_{4}\right)$ of $\beta_{41} X \beta y_{3}=(0,261 \times 0,280)$ $=0.0731$ with $\mathrm{z}$ value (Sobel Test) of $(3,222)$, path coefficient (mediation) indirect effect Transformational Leadership Style $\left(\mathrm{X}_{2}\right)$ to Productivity (Y) through Motivation $\left(\mathrm{X}_{4}\right)$ of $\beta_{42} \times \mathrm{y}_{4}$ $=(0.263 \times 0.280)=0.0736$ with a $\mathrm{z}$ value (Sobel Test) of $(3.190)$, and the path coefficient (mediation) influence is not Direct Communication $\left(\mathrm{X}_{3}\right)$ to Productivity $(\mathrm{Y})$ through Motivation $\left(X_{4}\right)$ of $\beta_{43} X \beta_{4}=(0,267 \times 0,280)=0,0748$ with $\mathrm{z}$ value (Sobel Test) of $(3,159)$.

Based on result and various existing limitations, researchers realizing that there are still other factors that influence the productivity of lecturers to produce international scientific work in Private Universities is the support of organizations in the form of training, equipment, expectations, and productive work of teams (Mathis \& Jackson, 2001: 84).

Furthermore, it is recommended to conduct a comprehensive study related to strategic efforts to improve the productivity of lecturers to produce international scientific work in private universities through research in both quality and quantity aspects. This is very important as an effort directed at expanding knowledge and opening new avenues of science and technology so that research results published in international journals are able to make important contributions 
to the growth and development of vital sectors of a country and encourage national and global development (Ifijeh, Ogbomo, \& Ifijeh, 2018).

\section{REFERENCES}

Agustini, F., Amanah, D., \& Harmen, H. (2014). Lecturer Through Development Of Learning Material In Medan City The Lecturer Empowerment For Increasing Work Productivity Of Management Lecturer Through Development Of Learning Material, (December 2017). https://doi.org/10.17605/OSF.IO/BXE4P

Ahmad, F., Abbas, T., Latif, S., \& Rasheed, A. (2014). Impact of Transformational Leadership on Employee Motivation in Telecommunication Sector, 2(2), 11-25.

Ahmadein, Ghada (2019) Obstacles and Opportunities for Achieving the SDGs at Higher Education Institutions: a Regional Arab Perspective in Implementing the 2030 Agenda at Higher Education Institutions: Challenges and Responses. First Edition Barcelona, September 2019 Coordination Global University Network for Innovation (GUNi) ISBN 978-84-09-13310-9 Contact info@guninetwork.org. http://www.guninetwork.org/files/guni_publication_-

implementing the_2030_agenda_at_higher_education_institutions_challenges_and_res ponses.pdf. Diakses 20 Desember 2019

Aithal, S. (2016). Munich Personal RePEc Archive How to Increase Research Productivity in Higher Educational Institutions - SIMS Model How to Increase Research Productivity in Higher Educational Institutions - SIMS Model, (71750).

Ajala, E. M. (2012). The Influence Of Workplace Environment On Workers' Welfare, Performance And Productivity. The African Symposium: An Online Journal of the African Educational Research Network, 12(1), 141-149.

Akafo, V., \& Boateng, P. A. (2015). Impact of Reward and Recognition on Job Satisfaction and Motivation. European Journal of Business and Management, 7(24), 112-124.

Al Doghan, M., \& Albar, S. (2015). A Study on Influence of Motivation Factors on Employees Performance in Private Schools in Saudi Arabia, (December), 179-187.

Alami, R. (2015). The Effectiveness of Human Resource Management on Improving the Performance of Education Staff. International Journal of Business and Social Science, 6(5), 251-254. Retrieved from www.ijbssnet.com

Aydin, A., Uysal, Ş., \& Sarier, Yi. (2013). The Effect of School Principals ' Leadership Styles on Teachers' Organizational Commitment and Job, 13(2), 806-811.

Buku Kekuatan 50 Institusi Ilmiah Indonesia Posted by Fitri | Dec 19, 2016 | Litabmas (DP2M), Pengumuman, https://lldikti12.ristekdikti.go.id/2016/12/19/buku-kekuatan-50-institusiilmiah-indonesia.html. Diakses April 12, 2018

Bushra, Fatima; Usman, Ahmad; \& Naveed, Asvir (2011) Effect of Transformational Leadership on Employees' Job Satisfaction and Organizational Commitment in Banking Sector of Lahore (Pakistan) nternational Journal of Business and Social Science Vol. 2 No.

18 ;

file:///C:/Users/user/Downloads/Effect_of_Transformational_Leadership_on_Employees. pdf. Diakses 27 November 2019

Boateng, Isaac (2014) A Quantitative Case Study of Transformational Leadership Characteristics of Valley View University in Ghana Andrews UniversityDigital Commons @ Andrews University repository@andrews.edu.

(2014).

Dissertations.https://digitalcommons.andrews.edu/cgi/viewcontent.cgi? article=1233\&conte $\underline{\mathrm{xt}=\text { dissertations. }}$. Diakses 27 November 2019

Chandrasekar, K. (2011). Workplace Environment And Its Impact On Organisational Performance In Public Sector, 1(1).

Danish, R. Q., \& Usman, A. (2010). Impact of Reward and Recognition on Job Satisfaction and Motivation: An Empirical Study from Pakistan, 5(2), 1-9.

Direktorat Pengelolaan Kekayaan Intelektual Direktorat Jenderal Penguatan Riset dan Pengembangan Kementerian Riset, Teknologi, dan Pendidikan Tinggi, Copyright (c). 
(2016).

Došenović, D. (2016). Employee Reward Systems in Organizations. Economics, 4(1), 107-118. doi:10 .1515/eoik-2015-0024, https://sci-hub.tw/https://doi.org/10.1515/eoik-2015-0024. Diiakses 27 November 2019

Eshak, E. S., Jamian, N. F., Jidi, M. M., \& Zakaria, N. Z. (2016). The Relationship Between Reward System With Employees ' Performance, 4, 10-15.

Fernandez, S., \& Pitts, D. W. (2011). Understanding Employee Motivation to Innovate: Evidence from Front Line Employees in United States Federal Agencies, 70(2), 202-222. https://doi.org/10.1111/j.1467-8500.2011.00726.x

Hanaysha, J. (2016). Management Science Letters, 6, 61-70. https://doi.org/10.5267/j.msl2015.11.006

HairJr, J. F., Hult, G. T. M., Ringle, C. M., \& Sage, M. S. (2013). A Primer on Partial Least Squares Structural Equation Modeling, 46, 184-185. https://doi.org/10.1016/j.lrp.2013.01.002

Ibrar, M., \& Khan, O. (2015). The Impact of Reward on Employee Performance ( A Case Study of Malakand, The Impact Of Reward On Employee ( A Case Study Of Malakand Private School) Muhammad Ibrar, Owais Khan. International Letters of Social and Humanistic Sciences, 52(May), 95-103. https://doi.org/10.18052/www.scipress.com/ILSHS.52.95

Ifijeh, B. A., Ogbomo, M. O., \& Ifijeh, G. (2018). Utilization Of Academic Library Resources For Research Productivity Among Lecturers In Private Universities In SouthSouth, (December).

Kim, Y., \& Ployhart, R. E. (2014). The Effects of Staffing and Training on Firm Productivity and Profit Growth Before, During, and After the Great Recession, 99(3), 361-389. https://doi.org/10.1037/a0035408

Luthfie, M., Hubeis, A. V. S., Saleh, A., \& Ginting, B. (2017). Climate Communication Society Organizations in the Development in the Village Plompong, 4(1), 10-23. https://doi.org/10.5296/jsss.v4i1.9894

Luthra, A., \& Dahiya, R. (2015). Effective Leadership is all About Communicating Effectively: Connecting Leadership and Communication. InternatIonal Journal of ManageMent \& BusIness StudIes, 5(3),3-8.

Mansor, M. F., Borhannuddin, S. N., \& Yusuf, B. N. M. (2014). The Effect of Rewards towards Job Performance among Chemical-Based The Effect of Rewards towards Job Performance among Chemical-Based Employees. International Journal of Business and Management Tomorrow, 2(12).

Mathis, R \& Jackson, J. H (2011). Human Resource Management. Terjemahan Diana Angelica. Jakarta: Penerbit Salemba Empat.

Mohamud, A., Ibrahim, A. A., \& Hussein, J. M. (2017). Original Research Article Original Research Article Open Access The Effect Of Motivation On Employee Performance : Case Study In Hormuud Company In Mogadishu Somalia, 07(2014), 17009-17016.

Money, V. O. (2017). Effectiveness of Transformational Leadership Style in Secondary Schools in Nigeria, 8(9), 135-140.

Muda, I., Rafiki, A., \& Harahap, M. R. (2014). Factors Influencing Employees 'Performance : A Study on the Islamic Banks in Islamic Science University of Malaysia University of North Sumatera, 5(2), 73-80.

Nabi, N., Foysol, K., \& Adnan, S. (2017). Arabian Journal of Business and The Role and Impact of Business Communication on Employee Performances, 7(3). https://doi.org/10.4172/2223-5833.1000301

Nazari, K., Basri, R. Bin, \& Idris, K. Bin. (2012). An Empirical Investigation Of Lecturers' Organizational Commitment In Technical And Vocationa Colleges In Iran. Journal of Arts, Science \& Commerce, 3(1), 1-10.

Okonedo, S.I. (2015). Research And Publication Productivity Of Librarians In Public Digitalcommons @ University Of Nebraska - Lincoln Productivity Of Librarians In Public Universities In South-West, (August 2015).

Olusadum, N. J., \& Anulika, N. J. (2018). Impact of Motivation on Employee Performance : A 
Study of Alvan Ikoku Federal College of Eduaction, 9(1), 53-65. https://doi.org/10.5430/jms.v9n1p53

Onanda, B. (2015). The Effects of Motivation on Job Performance A Case Study of KCB Coast Region, 5(9) ,1-13.

Osabiya, B. J. (2015). The effect of employees motivation on organizational performance, 7(May), 62-75. https://doi.org/10.5897/JPAPR2014.0300

Parvin, M. M., \& Kabir, M. M. N. (2011). Factors Affecting Employee Job Satisfaction Of Pharmaceutical Sector, 1(9), 113-123.

Pasban, M., \& Nojedeh, S. H. (2016). A Review of the Role of Human Capital in the Organization Procedia. Social and Behavioral Sciences, 230(May), 249-253. https://doi.org/10.1016/j.sbspro.2016.09.032

Pelinescu, E. (2015). The impact of human capital on economic growth. Procedia Economics and Finance, 22(November 2014), 184-190. https://doi.org/10.1016/S2212-5671(15)00258-0

Pendidikan Tinggi : 2.250 Profesor tak lakukan riset dan publikasi. https://beritagar.id/artikel/berita/2250-profesor-tak-lakukan-riset-dan-publikasi. Diakses15 Maret 2019

Peraturan Menteri Pemberdayaan Aparatur Negara dan Reformasi Birokrasi (Permen PAN-RB) Nomor 17 Tahun 2013 tentang Jabatan Fungsional Dosen dan Angka Kreditnya. (n.d.).

Peraturan Menteri Riset, Teknologi, Dan Pendidikan Tinggi Republik Indonesia Nomor 20 Tahun 2017 Tentang Pemberian Tunjangan Profesi Dosen Dan Tunjangan Kehormatan Professor (Permenristekdikti Nomor 20 Tahun 2017). (n.d.).

Rasool, S. F., Samma, M., Wang, M., Yan, Z., \& Zhang, Y. (2019).How Human Resource Management Practices Translate Into Sustainable Organizational Performance: The Mediating Role Of Product, Process And Knowledge Innovation. Psychology Research and Behavior Management, Volume 12, 1009-1025. doi:10.2147/prbm.s204662 https://www.dovepress.com/how-human-resource-management-practices-translate-intosustainable-org-peer-reviewed-fulltext-article-PRBM Diakses 20 Desember 2019

Robescu, O., \& Iancu, A. (2016). The Effects of Motivation on Employees Performance in Organizations, 7(2), 49-56. https://doi.org/10.1515/vjes-2016-0006

Saeed, R., Mussawar, S., Lodhi, R. N., Iqbal, A., Nayab, H. H., \& Yaseen, S. (2013). Factors Affecting the Performance of Employees at Work Place in the Banking Sector of Pakistan, 17(9), 1200-1208. https://doi.org/10.5829/idosi.mejsr.2013.17.09.12256

Sageer, A., Rafat, S., \& Agarwal, M. P. (2012). Identification of Variables Affecting Employee Satisfaction and Their Impact on the Organization, 5(1), 32-39.

Safiullah, IAyesha Binte (2014) Impact of Rewards on Employee Motivation of the Telecommunication Industry of Bangladesh: An Empirical Study OSR Journal of Business and Management (IOSR-JBM) e-ISSN: 2278-487X, p-ISSN: 2319-7668. Volume 16, Issue 12.Ver.II, PP 22-30 www.iosrjournals.org www.iosrjournals.org https://pdfs.semanticscholar.org/6e0e/d556b69a1dfad5360c41c9f04b036265e2c3.pdf.

Diakses 27 November 2019

Said, Nur Shafini Mohd; Zaidee, Amaleena Syamimie Ezzaty; Zahari, Ahmad Suffian Mohd; Ali, Siti Rapidah Omar; Salleh, Suzila Mat (2015). Relationship between Employee Motivation and Job Performance: A Study at Universiti Teknologi MARA (Terengganu) ISSN 2039-2117 (online) ISSN 2039-9340 (print) Mediterranean Journal of Social Sciences MCSER Publishing, Rome-Italy Vol 6 No 4 S2 July . Doi:10.5901/mjss.2015.v6n4s2p632, file:///C:/Users/user/Downloads/shafini.pdf. Diakses 27 November 2019

Sekaran, U., \& Bogie, R. (2016). Research Methods for Business: A Skill Building Approach (7th ed.). West Sussex: Jhon Wiley and Son, Ltd. https://doi.org/https://doi.org/10.13140/RG.2.1.1419.3126

Shahzadi, I., Javed, A., Pirzada, S. S., Nasreen, S., \& Khanam, F. (2014). Impact of Employee Motivation on Employee Performance, 6(23), 159-167.

Sanjiwani, M., Jayanegara, K., Eka, I. P., \& Kencana, N. (2015). Analysis Of Customer Satisfaction Satisfaction Restaurant Using Partial Least Square Method (Case Study : 
Burger King Bali ), 4(3), 98-103.

Undang - Undang (UU) No 12 Tahun 2012 Tentang Pendidikan Tinggi. (n.d.).

Undang - Undang (UU) No 14 Tahun 2005 Tentang Guru Dan Dosen. (n.d.).

Upev, M. T., Chorun, M. T., \& Idachaba, J. A. (2015). The Effects of Motivation on Staff Productivity/Performance at the Francis Sulemanuu Idachaba Library, University Of Agriculture, Makurdi-Nigeria, 5(2), 1-7. https://doi.org/10.9790/7388-05230107

Undang - Undang (UU) No 14 Tahun 2005 pasal 49 ayat 3. (n.d.).

Veliu, L., Manxhari, M., Demiri, V., \& Jahaj, L. (2017). Social sciences The Influence Of Leadership Styles On Employee' S Performance, 31(2), 59-69.

Voon, M. ., Ngui, K. S., Lo, M. ., \& Ayub, N. . (2011). The influence of leadership styles on employees' job satisfaction in public sector organizations in Malaysia, 2(1), 24-32.

Wasiu, B. O., \& Adebajo, A. (2014). Reward System And Employees Performance In Lagos State ( A Study Of Selected Public Secondary Schools ). Introduction :, 3(8), 14-28.

Weldeyohannes, G. (2015). Employee Motivation and Its Impact on Productivity in the Case of National

Alcohol and Liquor Factory ( NALF ), 15, 163-168.

Yamoah, E. E. (2013). Reward Systems and Teachers 'Performance : Evidence From Ghana, 9(5), 57-62. https://doi.org/10.3968/j.css.1923669720130905.2547

Zameer, H., Ali, S., \& Amir, M. (2014). The Impact of the Motivation on the Employee's Performance in Beverage Industry of Pakistan, 4(1), 293-298. https://doi.org/10.6007/IJARAFMS/v4-i1/630 